\title{
電子照射によるコバルトホウ化物のアモルファス化
}

\author{
坂田孝夫・森 博太郎・藤田広志 \\ (大阪大学超高圧電子顕微鏡センター, 565 吹田市山田丘)
}

\section{Crystalline to Amorphous Transition of Cobalt Borides under Electron Irradiation}

Takao SAKATA, Hirotaro MORI and Hiroshi FUJITA

(Research Center for Ultra-High Voltage Electron Microscopy, Osaka University, Yamada-oka, Suita-shi, Osaka

565)

\begin{abstract}
The electron irradiation-induced crystalline to amorphous $(C-A)$ transition in the Co- $B$ binary system was examined by ultra-high voltage electron microscopy. The five equilibrium phases (i.e., Co, $\mathrm{Co}_{3} B, \mathrm{Co}_{2} B, \mathrm{CoB}$, and $B$ ) in the system were irradiated with $2 \mathrm{MeV}$ electrons at a fixed temperature of approximately $110 \mathrm{~K}$, and the tendency towards the amorphization was compared. Of the five, only $\mathrm{Co}_{3} B$ and $\mathrm{Co}_{2} B$ underwent a $C-A$ transition by the irradiation while the other three remained crystalline. The tendency towards the amorphization under electron irradiation is best correlated with the position of the materials in the corresponding temperature-composition phase diagram; those compounds located near the bottom of the deep valleys of the liquidus in the diagram are rendered amorphous, while those which are located away from such valleys do not exhibit the $C-A$ transition.

[Received May 18, 1989 ; Accepted July 14, 1989]
\end{abstract}

Key-words : Cobalt boride, Electron irradiation, Radiation effect, Amorphous, Coordination number, HVEM.

\section{1. 緒言}

高エネルギー粒子線の照射によって誘起される結晶アモルファス遷移は, 古くから $\alpha$ 崩壊生成物を含む天 然鉱物 ${ }^{1}$ で起こることが知られていたが，その本格的な 研究は Matzke とWhitton による一連の非金属化合物の イオン照射実験 ${ }^{2}$ に始まると言える．彼らは，得られた 実験結果に基づいて, 結晶構造の対称性が照射損傷によ るアモルファス化能を左右する重要な因子であるとの提 案を行っている．この研究以降，金属並びに非金属化合 物を対象として, 結晶の照射誘起アモルファス化に関す る幾多の研究3) 9) が主にイオン照射法を用いて積み重ね られてきた。一方, 最近, $\mathrm{MeV}$ オーダーの高エネルギー 電子の照射によっても同様な結晶-アモルファス遷移の

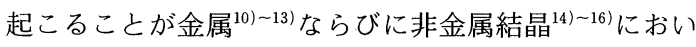
て, いずれも超高圧電子顕微鏡（以下電子顕微鏡を電顕 と略記）法によって発見された。一般に，この程度の工 ネルギーの電子照射によっては, 被照射材中の原子は, 電子との 1 回の衝突当たり 1 個あるいは 2 個はじき出し を受けるのみであり，イオン照射の場合にみられるカス ケード損傷は形成されない。このカスケード損傷の内部 では一種の液体（もしくはガス）の急冷凝固に似た過程 が生じていると考えられる ${ }^{17)}$ が，電子照射の場合にはそ うした急冷効果は一切含まれない。したがってこの発見 は，急冷効果の存在は粒子線照射による結晶のアモル ファス化の必要条件ではないことを初めて実証したもの として重要視されている ${ }^{18)}$. アモルファス物質を作製す
る上で急冷過程が必ずしも必要でないことは，例えば固 相反応法によってもアモルファス状態が得られる(19)こと から明らかであるが，高エネルギー電子照射法において は, こうした他の手法による場合とは違って, 組成の変 化を全く伴わない単純条件下で単相から単相へのアモル ファス遷移が達成される特徵を備えている。したがって, この手法による場合には，結晶-アモルファス遷移を構 成原子間の配置の変化（もしくは配位の変化）という最 も単純な観点から解析することが可能であり，そのよう な整理を通してアモルファス形成の難易や，更にはその 支配因子に関する情報を得ることができる，著者らのグ ループでは，このような視点から，系統的に選んだ一連 の金属化合物 ${ }^{20)}$ なびに非金属化合物 ${ }^{21)}$ についてその電 子照射誘起アモルファス化能を調べ，得られた結果に基 づいてアモルファス形成の一般法則について検討を加え ている ${ }^{22,23)}$. 本研究は, ホウ化物セラミックスの電子照 射誘起アモルファス化に関する研究の一環として，コバ ルトホウ化物のアモルファス化能を明らかにしようとす るものである.すなわち，Co-B 2 元系に存在するすべ ての化合物 $\left(\mathrm{Co}_{3} \mathrm{~B}, \mathrm{Co}_{2} \mathrm{~B}\right.$ 及び $\mathrm{CoB}$ の 3 個の化合物 $)$ ならびに純物質のコバルトとホウ素を試料として選び, それらのアモルファス化能を超高圧電顕法によって明ら かにするとともに, 得られた結果に対して考察を加えた.

\section{2. 実験方法}

\section{1 試料}




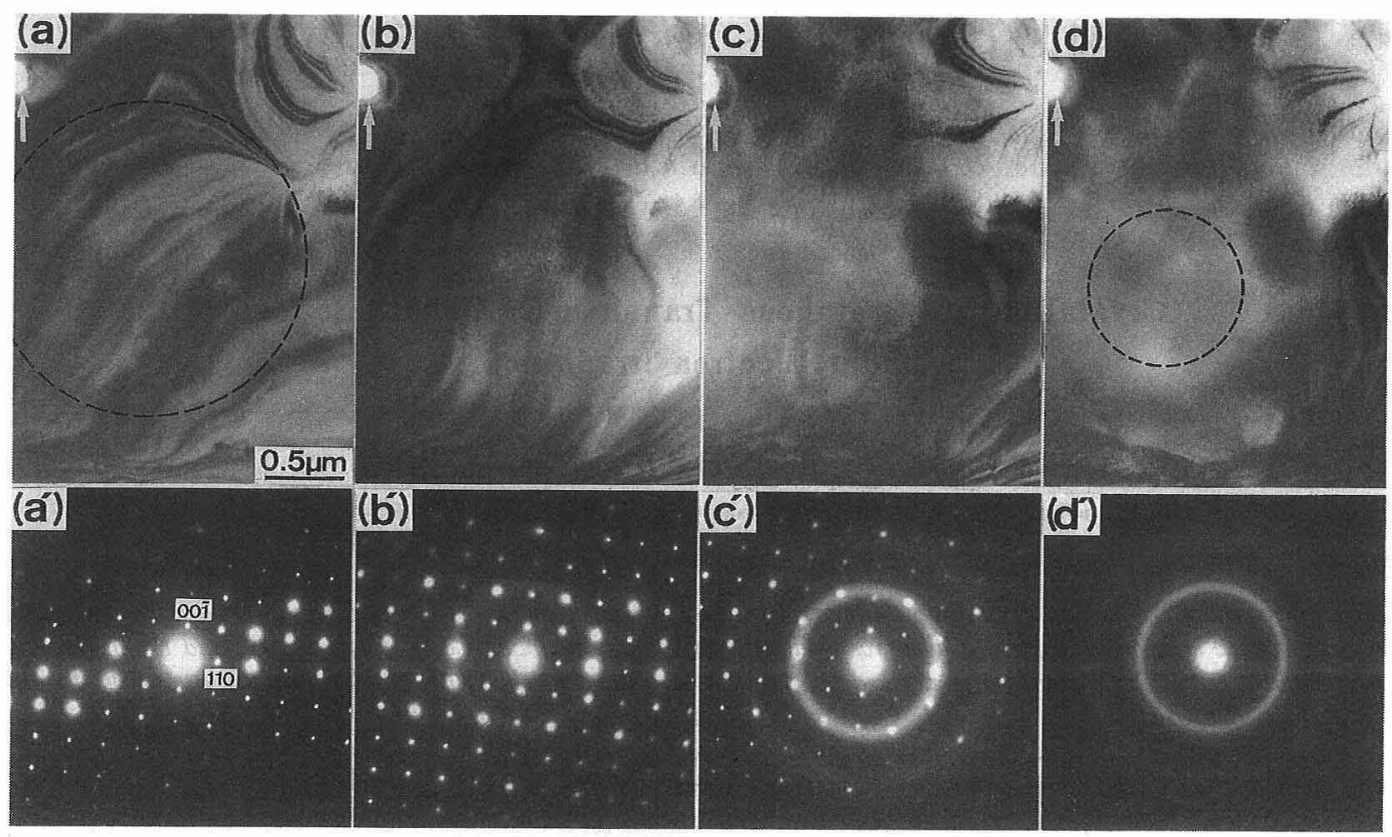

Fig. 1. Successive stages of the amorphization of $\mathrm{C}_{3} \mathrm{~B}$ by $2 \mathrm{MeV}$ electron irradiation with corresponding diffraction patterns. Irradiation temperature $T$ and flux $\phi$ are $120 \mathrm{~K}$ and $1.5 \times 10^{24} \mathrm{e} / \mathrm{m}^{2} \mathrm{~s}$, respectively. (a) Before irradiation, (b) after $60 \mathrm{~s}$ irradiation, (c) after $120 \mathrm{~s}$ irradiation, (d) after $240 \mathrm{~s}$ irradiation. The circle in (a ) depicts the size and position of the irradiated area, whereas the circle in $(d)$ shows those of the SA aperture.

純度 99.5 at\% のコバルトと純度 99.9 at\% のホウ素 を用いて，アークメルト法により，Co-5 at％ B 及び Co- 40.7 at\% B の 2 種類の組成の合金を溶製した. 溶 解に当たっては,アーク炉内の酸素分圧を下げる目的で, あらかじめジルコニウムを溶解して液体状態に 300 秒間 保持した．試料溶解時の雾囲気ガスとしては，1 気圧の 高純度のアルゴンを用い, 各合金とも約 5 グラムのボ夕 ンを作製した。これらのボタン状合金に $1173 \mathrm{~K} ， 86.4$ ks の焼鈍を施して，Co-5 at\% B 合金はコバルトと $\mathrm{Co}_{3} \mathrm{~B}$ の二相合金に，また $\mathrm{Co}-40.7$ at \% B 合金は $\mathrm{Co}_{2} \mathrm{~B}$ と $\mathrm{CoB}$ の二相合金にそそれぞれ変態させて試料とした. 純物質のコバルトとホウ素についてもそれぞれ約 5 グラ ムのボタンを溶製して試料とした。電顕観察用の薄膜試 料は, これらのボタン状試料から放電加工機によって $0.4 \mathrm{~mm}$ 厚の板状試片を切り出した後, これに機械研磨 と電解研磨を施して作製した．機械研磨は $\mathrm{SiC}$ 研磨紙 を用いて手研磨により行い， $50 \mu \mathrm{m}$ 厚の薄板を得た。電 解研磨は硝酸，メチルアルコールの混合液によるジェッ 卜研磨と酶酸, 過塩素酸の混合液による仕上げ研磨を併 用して行った。

\section{2 電子線照射}

電子線照射は日立 HU-3000 型超高電圧電子顕微鏡を 用いて, 加速電圧 $2 \mathrm{MV}$, 照射強度 $1.5 \times 10^{24} \mathrm{e} / \mathrm{m}^{2} \mathrm{~s}$, 武 料温度 100 110 Kの一定条件下で行い，照射の進行に 伴う組織と構造の変化をそれぞれ明視野像と制限視野回
折図形によってその場観察した．照射には直径約 $2 \mu \mathrm{m}$ の収束ビームを用いた．ビーム加熱による試料の温度上 昇が考えられるため, 予備実験として試料上に島状のイ ンジウムを蒸着して, このインジウムの溶解温度から ビーム加熱の効果を評価する実験を行った，その結果 $10 \mathrm{~K}$ の温度上昇が認められた。そこで, 第 3 章に示す 実験結果においては, 試料温度の測定值に $10 \mathrm{~K}$ を加算 した值を照射温度として表示した.なお, 使用した電子 顕徴鏡の試料室は常に $5 \times 10^{-5} \mathrm{~Pa}$ 以上の真空度に保た れており，照射実験中の試料のコンタミネーションは特 に問題とはならなかった。

\section{3. 結 果}

$\mathrm{Co}-\mathrm{B} 2$ 元系平衡状態図には, $\mathrm{CO}_{3} \mathrm{~B}, \mathrm{Co}_{2} \mathrm{~B}$ 及び $\mathrm{CoB}$ の 3 個の化合物に純物質のコバルトとホウ素を加 えた合計 5 種類の固相が存在する。この中で, $\mathrm{Co}_{3} \mathrm{~B}$ 亡 $\mathrm{Co}_{2} \mathrm{~B}$ は電子照射によって完全にアモルファス化する が, 残りの $\mathrm{CoB}$, コバルト及びホウ素は結晶を保つ. 以下にこれらの結果を詳述する.

\section{$3.1 \mathrm{Co}_{3} \mathrm{~B}$ 及び $\mathrm{Co}_{2} \mathrm{~B}$ の電子照射によるアモルファス 化}

最初に, $\mathrm{Co}_{3} \mathrm{~B}$ におけるアモルファス化過程を連続的 に観察した結果を図 1 に示す。図 1 (a)，（b ），(c), 及び（d）は，それぞれ照射前， 60 秒， 120 秒及び 240 秒照射後の同一個所の明視野像を示す. 各写真中, 白い 

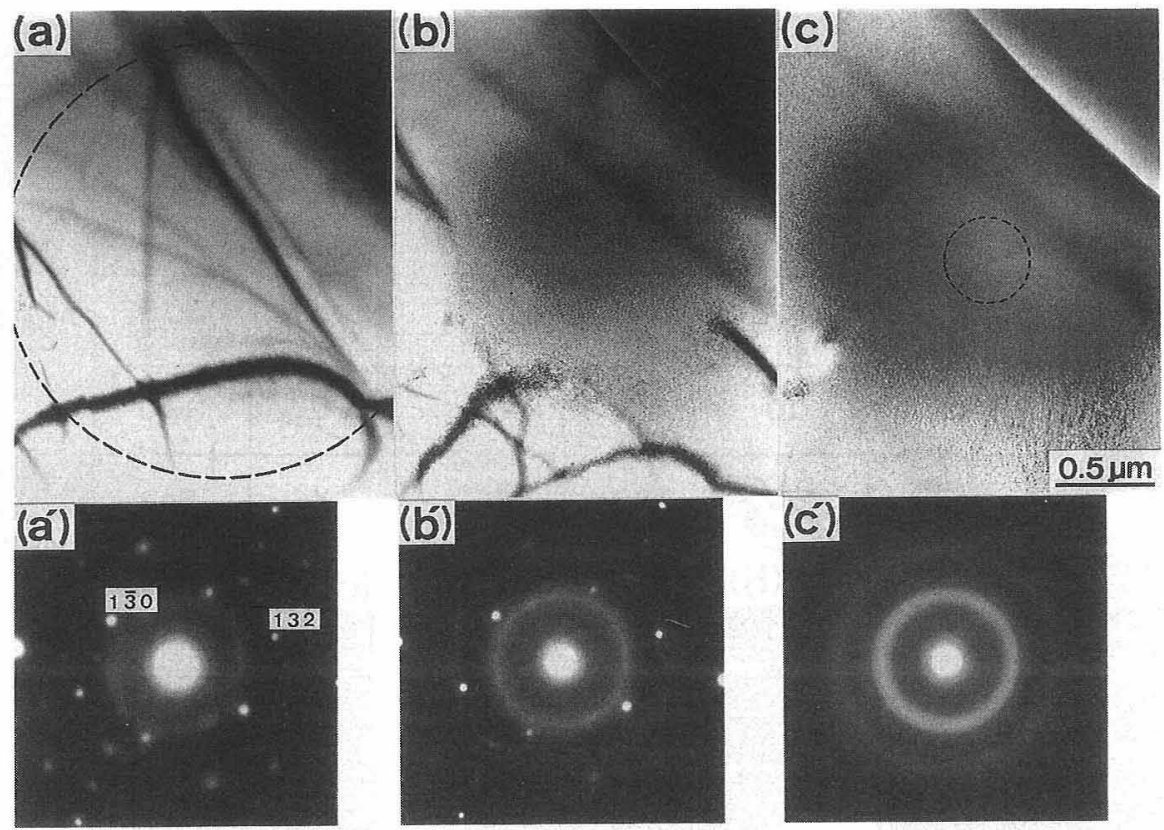

Fig. 2. Successive stages of the amorphization of $\mathrm{Co}_{2} \mathrm{~B}$ by $2 \mathrm{MeV}$ electron irradiation with corresponding diffraction patterns. Irradiation temperature $T$ and flux $\phi$ are $110 \mathrm{~K}$ and $1.5 \times 10^{24} \mathrm{e} / \mathrm{m}^{2} \mathrm{~s}$, respectively. (a) Before irradiation, ( b ) after $0.3 \mathrm{ks}$ irradiation, (c) after $1.8 \mathrm{ks}$ irradiation.

矢印は同一個所を指すマーカーである，照射領域の位置 ならびに大きさは, 図 1 ( a ) に破線の円で示されてい る. 図1 ( $\left.a^{\prime}\right) ，\left(b^{\prime}\right) ，\left(c^{\prime}\right)$ 及び (d') は，それぞれ図 1 ( a )，（b ），(c) 及び（d）に対応する制限視野回折 図形であり, 照射領域の中央部 (一例を図 1 (d) に破 線の円で示す) に制限視野絞りをセットして撮られたも のである．照射を開始すると，図1（b ）に示すように， 照射領域内の等傾角消衰縞 (bend contour) は次第にそ のコントラストを弱めはじめ, 照射量の増加とともに, この現象は徐々に進行する. これに対応して, 回折図形 においては, $\mathrm{Co}_{3} \mathrm{~B}$ の網状スポット図形に重盢してアモ ルファス特有のハロー図形が現れ（図 $\left.1\left(b^{\prime}\right)\right)$, その強 度は照射量の増加とともに強くなる一方, スポット図形 の強度は減衰する (図 $\left.1\left(c^{\prime}\right)\right)$. そして, 更に照射を続 けると，最終的には図 1 (d) に示すように照射領域か ら等傾角消衰縞をはじぬとするすべてのブラッグ反射の コントラストが消滅すると同時に, 回折図形においても すべての回折斑点が消滅してハロー図形に変化する（図 1 (d')). 以上の観察から, $\mathrm{Co}_{3} \mathrm{~B}$ 化合物は 240 秒程度の 電子照射によって完全にアモルファス化すると結論でき る.

図 2 は $\mathrm{Co}_{2} \mathrm{~B}$ におけるアモルファス化過程をその場観 察した結果の一例であり，(a)，（b）及び（c）は， それぞれ照射前， 300 秒及び 1800 秒照射後の同一個所 を明視野像にて観察したものである。図 2（a）中, 破 線の円は照射領域を示す。図 2 (a'), (b') 及び (c')
はそれらの各照射段階に対応した回折図形であり，照射 領域の中央部（一例を図 2 (c) に破線で示す）に制限 視野絞りをセットして撮影したものである.この図から， $\mathrm{Co}_{2} \mathrm{~B}$ を電子照射すると, 図 1 に示す $\mathrm{Co}_{3} \mathrm{~B}$ の場合と同 様に，明視野像においては最終的に照射領域からすべて のブラッグ反射コントラストが消滅する（図 2（c）） と同時に，回折図形はスポット図形（図2 (a')) から 八ロー図形（図 $2\left(c^{\prime}\right)$ ) に変化することが分かる．以 上の結果から， $\mathrm{Co}_{2} \mathrm{~B}$ は 1800 秒程度の電子照射によっ て完全にアモルファス化すると結論される.

\section{$3.2 \mathrm{CoB}$, コバルト及びホウ素における照射損傷挙} 動

$\mathrm{CoB}$ の照射損傷挙動を図 3 に示す. 図 3 ( a ), (b) 及び (c) はそれぞれ照射前，1200 秒及び 3600 秒照射 後の明視野像であり，図 $3\left(a^{\prime}\right)$, (b') 及び (c') はそ れらに対応した制限視野回折図形を示す. 図 3（a）中 の破線の円は照射領域を示す. また, 図 3 ( a ) （c ） 中の矢印は同一個所を指すマーカーである. 図 3(b) から分かるように，照射を開始すると照射領域全域にわ たって微小な二次欠陥が高密度に形成される. 更に照射 を続けると，図 3 （c）に見られるように，これらの二 次欠陥はそのサイズを増大させる，しかしながら，この 間回折図形に変化は見られず（図 3 ( (b'), (c')), 結晶アモルファス遷移の兆候は全く認められない.

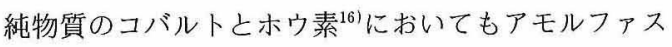
化の兆候は全く認められなかった. 

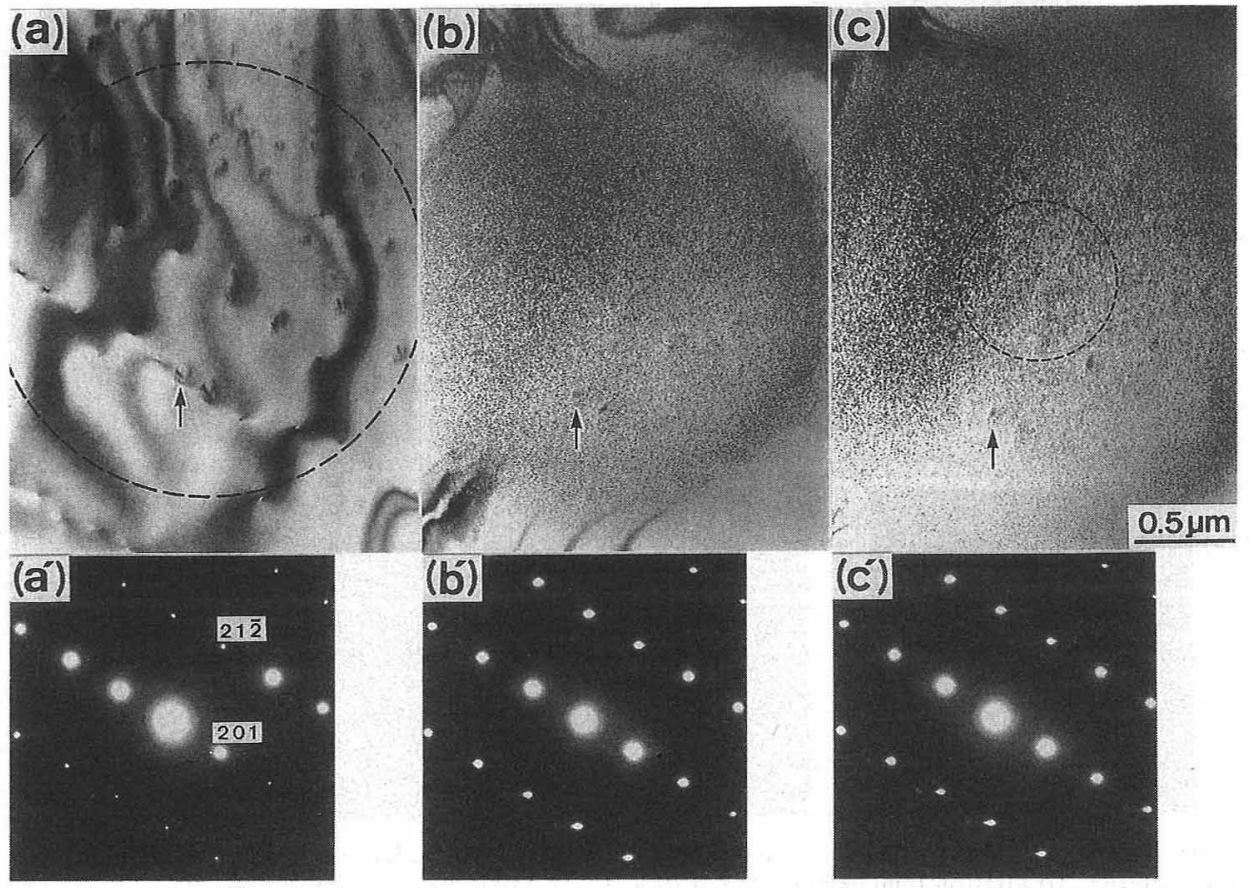

Fig. 3. In-situ irradiation sequence showing defect aggregation in $\mathrm{CoB}$. The arrows indicate a fixed position. $E=2 \mathrm{MeV}, T=110 \mathrm{~K}, \phi=1.5 \times 10^{24} \mathrm{e} / \mathrm{m}^{2} \mathrm{~s}$. ( a ) Before irradiation, ( b ) and ( c ) after $1.2 \mathrm{ks}$ and $3.6 \mathrm{ks}$ irradiation, respectively.

\section{4. 考 察}

著者らのグループは，さきに， $\mathrm{SiC}^{(4)}$ に加えて $\mathrm{B}_{4} \mathrm{C}^{16)}$ が高エネルギー電子照射によってアモルファス化するこ とを見いだし，高エネルギー電子照射による結晶のアモ ルファス化は，金属化合物のみならず非金属化合物にお いても見られる一般的な現象であることを明らかにし だ.この $\mathrm{B}_{4} \mathrm{C}$ における観察を契機として，著者らはホ ウ化物セラミックスの電子照射誘起アモルファス化に関 する系統的な研究を開始し，その第一報であるニッケル ホウ化物の結果を本誌 ${ }^{24)} に$ 報告した. すなわち, 平衡相 として存在する 5 種類のニッケルホウ化物の中で, $\mathrm{Ni}_{2} \mathrm{~B}$ と $\mathrm{o}-\mathrm{Ni}_{4} \mathrm{~B}_{3}$ の 2 種類の化合物がアモルファス化す ることを報告した.これに続く今回の実験では，3 種類 のコバルトホウ化物の中で $\mathrm{CO}_{3} \mathrm{~B}\left\llcorner\mathrm{Co}_{2} \mathrm{~B}\right.$ の 2 種類の化 合物が同様にアモルファス化することが新たに判明し， $1 \mathrm{MeV}$ 電子を用いて行われた $\mathrm{Fe}_{3} \mathrm{~B}$ における実験の結

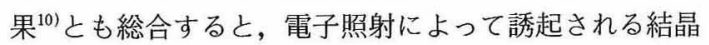
-アモルファス遷移は遷移金属ホウ化物においても高い 頻度で観察される現象であることが分かる.

次に, Co-B 二元系に存在する 5 種類の平衡固相, す

* $\mathrm{SiO}_{2}$ が比較的低エネルギーの電子照射によってアモルファ ス化する現象は古くから知られている（例えば，L.W． Hobbs and M. R. Pascucci, J. de Phys., 41, C 6, 237-42 （1980）など）が,これはイオン化損傷によるものと考え られており,ここで取り扱うはじき出し損傷によるアモル ファス化の議論からは除外する.
なわち, $\mathrm{Co}, \mathrm{Co}_{3} \mathrm{~B}, \mathrm{Co}_{2} \mathrm{~B}, \mathrm{CoB}$ 及び $\mathrm{B}$ 中中で, $\mathrm{Co}_{3} \mathrm{~B}$ と $\mathrm{Co}_{2} \mathrm{~B}$ だけがアモルファス化する点について考察を加 える、第一報にも述べたとおり，結晶の照射誘起アモル ファス化に関する研究は従来主にイオン照射法を用いて 進められてきた歴史があり，イオン照射時のアモルファ ス化の難易に対してはこれまでにいくつかの判断基準 (criterion) が提案されている. その代表的なものを列 挙すると, (1)結晶構造の対称性の悪いものほどアモル ファス化しやすく, 対称性のよい例えば立方晶結晶はア モルファス化しにくいとする structure-type criterion ${ }^{2)}$, (2)イオン化度が 0.47 以下の化合物はアモルファス化し やすいとする bond-type criterion ${ }^{3)}$ ，及び(3)状態図上で 固溶範囲の小さな化合物ほどアモルファス化しやすいと する solubility criterion ${ }^{7)}$ ，等がある. 今回の結果がこ れらの判断基準によって整理できるか否かを調べる目的 で, 各平衡固相の結晶系, 結晶構造 (あるいは空間群), イオン化度，固溶範囲を表 1 にまとめて示す. 表 1 の第 二列目は電子照射下でのアモルファス化の有無を示すも ので，アモルファス化する固相には○印を，またしない ものにはメ印をそれぞれ付した. 上述の structure-type criterion 及び bond-type criterion は，本来非金属化合 物に対する判断基準であることもあって, 表 1 から分か るように，今回の結果はこれらの基準によっては説明で きない，すなわち，アモルファス化する $\mathrm{Co}_{3} \mathrm{~B}$ と $\mathrm{Co}_{2} \mathrm{~B}$ の二つの化合物は他の固相に比べて特に対称性の低い結 
Table 1. Crystal stability under electron irradiation of all phases in Co-B binary system. Various physical parameters for the phases are also included.

\begin{tabular}{|c|c|c|c|c|c|}
\hline compound & responce & $\begin{array}{c}\text { crystal } \\
\text { system }\end{array}$ & $\begin{array}{c}\text { crystal } \\
\text { structure }\end{array}$ & ionicity & $\begin{array}{c}\text { extent of } \\
\text { solubility (at\%) }\end{array}$ \\
\hline Co & $X$ & hexagonal & $A 3$ & - & none \\
\hline Co3B & 0 & $\begin{array}{c}\text { ortho- } \\
\text { rhombic }\end{array}$ & $D_{2 h^{16}}$ & 0.01 & none \\
\hline Co2B & 0 & tetragonal & $\mathrm{Cl} 6$ & 0.01 & none \\
\hline CoB & $X$ & $\begin{array}{c}\text { ortho- } \\
\text { rhombic }\end{array}$ & $B 27$ & 0.01 & none \\
\hline$B$ & $X$ & hexagonal & $D_{30}{ }^{5}$ & - & none \\
\hline
\end{tabular}

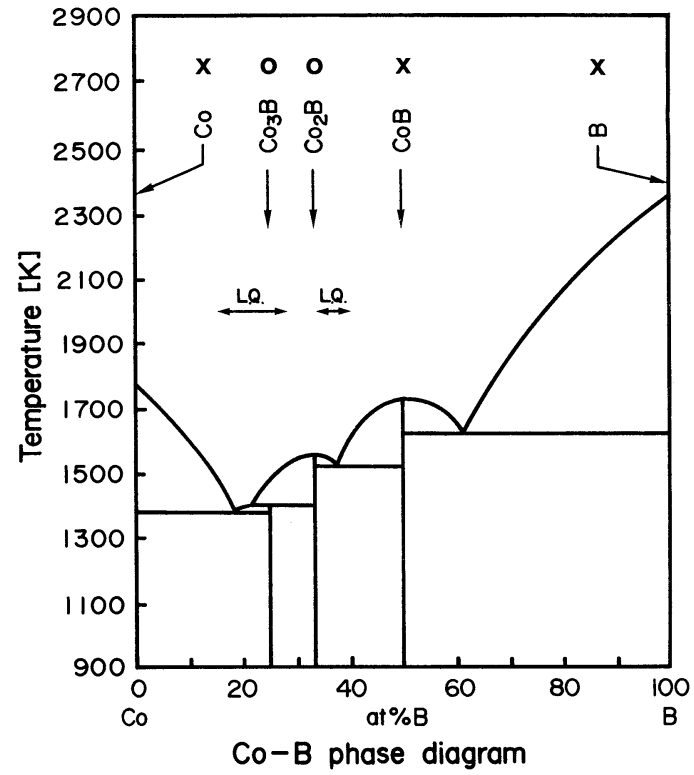

Fig. 4. Co-B phase diagram. Marks $\bigcirc$ and $\times$ labelled on each phase represent the presence and absence of the crystalline to amorphous transition induced by electron irradiation, respectively. The composition range over which amorphous materials can successfully be obtained by rapid liquid quenching is indicated (L. Q. ).

晶構造を有するわけでもなく，またイオン化度が低いわ けでもない. 更に, 五つの固相とも固溶範囲はほとんど 0 であり, solubility criterion も成立しない. したがっ て, 本研究で明らかになったコバルトホウ化物のアモル ファス形成傾向は従来の判断基準では整理することが困 難である.

そこで次に，第一報のニッケルホウ化物の場合と同様 に,アモルファス形成能を平衡状態図上での各固相の位 置の関数として整理することを試みた. 得られた結果を
図 4 に示す. 図中，各相に付した○及びメ印は，アモル ファス化の有及び無をそれぞれ示す. 図 4 から分かるよ うに，五種類の固相の中でアモルファス化する $\mathrm{Co}_{3} \mathrm{~B}$ 及 び $\mathrm{Co}_{2} \mathrm{~B}$ はいずれも，コバルト及びホウ素の融点から降 下する 2 本の液相線が形作る液相領域の深い谷の底近傍 に位置しており，これらの化合物の組成は液体急冷法に よってアモルファスが形成される組成範囲 ${ }^{25)}$ (図中,

L.Q. と表示）に含まれるかもしくは極めて近接してい る.こうした電子照射下のアモルファス形成能と当該化 合物の平衡状態図上での位置との相関，すなわち，液相 領域の深い谷近傍に位置する化合物ほぼ容易にアモル ファス化する傾向は，第一報に示した $\mathrm{Ni}-\mathrm{B}$ 二元系のほ か, 遷移金属同士の二元系や遷移金属-アルミニウム二 元系においても広く認められる ${ }^{201}$.これらの事実から， 結晶の照射下におけるアモルファス化能を議論するため には，表 1 に挙げたような単一のパラメーターを用いる のでなく, 状態図の形やその中での位置のような, 構成 原子間の相互作用に関するより総合的な情報を包含した パラメーターを用いる必要のあることが分かる.

ここで電子照射による結晶のアモルファス化はどのよ うな原子的な過程を経て生じるのかについて検討する. 図 5 は, 今回アモルファス化することの判明した $\mathrm{Co}_{3} \mathrm{~B}$ 化合物の結晶構造を模式的に描いたもので，白丸印はコ バルト原子を，またハッチングを入れた丸印はホウ素原 子をそれぞれ表す。この図から， $\mathrm{Co}_{3} \mathrm{~B}$ 化合物中では, ホウ素原子のまわりのコバルト原子の配置は三角プリズ 厶型 6 配位をとることが分かる（例えば，図中右下の太 線で描いた三角プリズムを参照のこと). $\mathrm{Co}_{3} \mathrm{~B}$ 化合物 の敷居変位エネルギー（結晶中の構成原子を正規の格子 位置からはじき出すために必要な最低のエネルギー）は これまでに測定例がなく不明であるが，いま仮にこれが 同一構造をとる $\mathrm{Fe}_{3} \mathrm{~B}$ 化合物の鉄に対して求められた值 


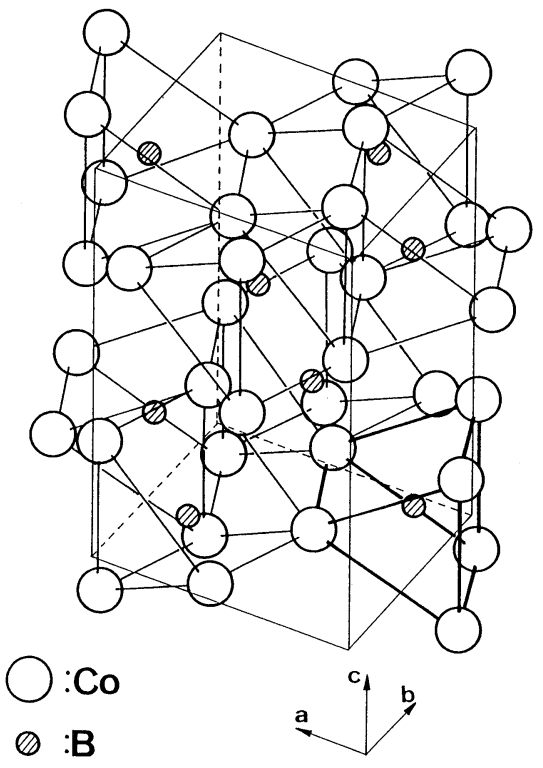

Fig. 5. Crystal structure of $\mathrm{Co}_{3} \mathrm{~B}$ (schematic).

の $22 \mathrm{eV}^{26)}$ に等しいと仮定すると, 今回の電子照射条件 下では毎秒およそ $10^{-2} \mathrm{dpa}$ (displacement per atom) の割合で $\mathrm{Co}_{3} \mathrm{~B}$ 中の構成原子のはじき出しが生ずること になる.これはちょうよ゙，1秒間に，結晶を構成する原 子の 100 個に 1 個がはじき出しを受ける割合に相当す る.このようにはじき出しを受けた原子は，空孔が熱的 に移動できる高温では一般に容易にそれぞれの副格子点 に戻る ${ }^{27)}$ ことが可能であり，したがってもとの $\mathrm{Co}_{3} \mathrm{~B}$ 化 合物の結晶構造は保持される. しかし, 今回の照射温度 ( 110 K) のような低温では空孔は熱的には不動であ り，はじき出し損傷を受けた副格子の修復，したがって もとの $\mathrm{Co}_{3} \mathrm{~B}$ 化合物の結晶構造の維持は困難となる.こ の点をいま少し具体的に考えてみよう. 電子との衝突に よってはじき出しを受けたコバルト原子は格子間原子 に，またそれが占めていたもとの格子点は空孔にそれぞ れ変化するが,このようなはじき出し損傷は, 必然的に, 関与した原子の配位数の変化をもたらす.すなわち, 格 子間原子となったコバルト原子はもちろん，これに隣接 するコバルト原子ならびにホウ素原子, さらには形成さ れた空孔に隣接する構成原子はいずれも配位数の変化を 受ける.このような配位数の変化は, 配位にあずかる原 子間の平衡距離を伸縮させると同時に平衡結合角を変化 させ ${ }^{23)}$, その結果局所的に結晶格子の周期性を乱す. 殊 に, ホウ素, リン, シリコン, ゲルマニウム等の化合物 においては，これらのメタロイドがその置かれている原 子的な環境に合わせて自己の原子容を大きく変化させう る特性を備えている ${ }^{281}$ 関係上, こうした損傷に基づく局 所的な原子間距離ならびに結合角の変化は格段に顕著之 なり，結晶格子を大きく歪ませるに至る，すなわち，例
えばさきに述べた三角プリズムのコーナーに位置するコ バルト原子がはじき出しを受けてホウ素原子が 5 配位に 変化したとすると, 当該三角プリズムの外形の大略は保 存されるとしても, 格子間原子となったコバルト原子や それに近接する構成原子は互いに局所的に安定な結合を 起こして単位胞内の他の原子との相対位置にずれを生じ る. その結果, 原子配列の周期性に乱れを生じるに到る. 空孔が熱的に不動となる低温照射では, このような, 配 位数が局所的に変化した状態が効率よく凍結されるため に, それに付随する格子の乱れもまた照射量の増加とと もに漸次蓄積されて, 遂には結晶格子の長範囲にわたる 周期性が失われてアモルファス化するものと考えられる

（予備実験によって $\mathrm{Co}_{3} \mathrm{~B}$ 化合物は $160 \mathrm{~K}$ 以上の高い照 射温度ではアモルファス化せずに結晶を保つことを確か めた). 従来, 結晶の電子照射損傷の研究は, 二次欠陥 の形成・成長挙動の観察に基づいて点欠陥の生成やその 移動特性を明らかにすることに主眼が置かれており ${ }^{29)}$, そこでは個々の点欠陥は結晶格子中を熱的にランダムに 拡散するとともにそのような拡散を通して相互に離散集 合することが前提条件となっている. しかし, 電子照射 によるアモルファス化という損傷は, 上に述べた一つの モデルからも分かるように，そのような個々の点欠陥の 単なる離散集合を規定する因子によってではなく,より 構成原子の多体間の相互作用を強く反映したいわば構造 化学的な因子によって支配されていると考えられる.

最後に, $\mathrm{Co}-\mathrm{B}$ 二元系の $\mathrm{Co}_{3} \mathrm{~B}$ と $\mathrm{Co}_{2} \mathrm{~B}$ がそうである ように, 平衡状態図上で液相領域の深い谷近傍に位置す る化合物は電子照射で容易にアモルファス化する傾向に ついて考察を加える. 平衡状態図は各相の自由エネル ギーの温度変化を反映したものであり, 上述の傾向は, 化合物の照射下でのアモルファス形成能が自由エネル ギーという一つの状態変数によってある程度整理できる ことを示している。一般に, 固相の自由エネルギーは温 度の低下とともに同一組成の液相のそれに対して相対的 に低下するが, 液相領域の谷近傍に位置する化合物は他 の高い融点をもつ化合物に比べてより低温度（ほぼその 融点に近いと考えてよい）にて液相と等しい自由エネル ギー值をとった後, 更に低温の照射温度に到る.したがっ て, 同一の照射温度で比較すると, これらの化合物は高 い融点の化合物に比べてより液相（過冷液相）の自由エ ネルギーに近い自由エネルギーを持つことになる. 先に 述べたアモルファス化の原子的な機構のモデルからも明 らかなように, 結晶の周期性の乱れは, 局所的には安定 な結合（場合によっては結晶相本来の結合よりも安定な 結合）を生むにしても, 系全体としては自由エネルギー の上昇を不可避的にもたらす.したがって, いま, 化合 物の自由エネルギーが照射量とともにこのような周期性 の乱れによって漸増し, 遂に液相（過冷液相）のそれに 
等しくなった状態をアモルファス化の完了した状態と定 義するならば, 液相の谷近傍に位置する化合物ほど固相 と液相 (過冷液相) の自由エネルギー差が小さいために, 容易にアモルファス化することが考えられる. 一般に非 平衡相が平衡相に移る遷移の難易に対しては, 大きく分 けて, 自由エネルギー差を実体とする遷移の駆動力に係 わる因子亡, 具体的な原子の移動を律速する速度論的因 子の二つが重要なパラメーターであると認められてい る. 今回の実験のように, 平衡相 (化合物結晶) を非平 衡相 (アモルファス) に遷移させる場合も, このような 駆動力（この場合自由エネルギー差は正となる）に係わ る因子と速度論的因子の二つの因子によって遷移の難易 が規定されるとすると, 上に得た結論は前者, すなわち 駆動力の大小が基本的に重要な因子であることを示して いる.

アモルファス化の難易と当該化合物の状態図上での位 置が何故高い相関を示すのかを明らかにする目的で,こ こでは一つの自由エネルギー的な議論を行った.この議 論の当否については, 例えば結晶化に伴うエンタルピー 変化が固相と液相 (過冷液相) の自由エネルギ一差に見 合うものであるかどうかなどの, より定量的な実験事実 との比較を行った後で, 最終的な判断を下したいと考え る.

\section{5. 結 言}

コバルトホウ化物の電子照射誘起による結晶-アモル ファス遷移を超高圧電顕法によって調べた。すなわち, Co-B 二元系に存在するすべての化合物 $\left(\mathrm{Co}_{3} \mathrm{~B}, \mathrm{Co}_{2} \mathrm{~B}\right.$ 及び $\mathrm{CoB})$ ならびに純物質のコバルトとホウ素を試料 として選び，それらが $2 \mathrm{MeV}$ 電子の低温 $(\sim 110 \mathrm{~K})$ 照射によってアモルファス化するか否かをその場観察し た. 得られた結果は以下のように要約される.

(1) 上述の 5 種類の平衡固相の中で, $\mathrm{Co}_{3} \mathrm{~B}$ は約 240 秒また $\mathrm{Co}_{2} \mathrm{~B}$ は約 1800 秒の照射（電子線強度 $1.5 \times$ $\left.10^{24} \mathrm{e} / \mathrm{m}^{2} \mathrm{~s}\right)$ によってそれぞれ完全にアモルファス化す る.しかし, $\mathrm{CoB}$ と純物質のコバルト及びホウ素は結 晶を保つ。

(2) $\mathrm{Co}_{3} \mathrm{~B}$ と $\mathrm{Co}_{2} \mathrm{~B}$ 化合物だけが強いアモルファス 形成傾向を示す理由は, 従来イオン照射下でのアモル ファス化能に対して提唱されている criterionによって は説明できない，これらの二つの化合物は，先に報告し たニッケルホウ化物の場合と同様に, いずれも平衡状態 図上で液相領域が深い谷を形作る組成範囲内に位置する
特徴を備えている.このような当該化合物の状態図上で の特徵は, 遷移金属同士の化合物や遷移金属アルミナイ ドの場合にも共通して認められることから，アモルファ ス化能を決める本質的な因子を直接反映するものである と考えられる.

\section{文献}

1) A. Pabst, Am. Mineral., 37, 137-57 (1952).

2) Hj. Matzke and J.L. Whitton, Can. J. Phys., 44, 995-1010 (1966).

3) H. M. Naguib and R. Kelley, Rad. Eff., 25, 1-12 (1975).

4) D. G. Walker, J. Nucl. Mater., 37, 48-58 (1970).

5) J. M. Howe and R.H. Rainville, J. Nucl. Mater., 68, 215-34 (1977).

6) M. D. Rechtin et al., Scripta Met., 12, 639-43 (1978).

7) J.L. Brimhall et al., Scripta Met., 13,.217-20 (1979).

8) P. Moine et al., Nucl. Instr. Meth., 209/210, 267-72 (1983).

9) J. L. Brimhall et al., Rad. Eff., 77, 237-93 (1983).

10) A. Mogro-Campero et al., Metastable Materials Formation by Ion-Implantation, N-H, New York (1982) pp. 203-10.

11) H. Mori and H. Fujita, Jap. J. Appl. Phys., 21, L494-96 (1982).

12) G. Thomas et al., Scripta Met., 16, 589-92 (1982).

13) H. Mori et al., Scripta Met., 18, 783-88 (1984).

14) H. Inui and H. Fujita, Proc. XI th Int. Cong. on EM, Kyoto, 1135-36 (1986).

15) C. Kinoshita et al., Proc. XI th Int. Cong. on EM, Kyoto, 1097-98 (1986).

16) H. Inui, H. Mori and H. Fujita, Scripta Met., 22, 249-54 (1988).

17) P. Ziemann, Mat. Sci. and Eng., 69, 95-103 (1985).

18) Y. Limoge et al., J. Non-Cryst. Solids, 99, 75-88 (1988).

19) R. B. Schwarz and W. L. Johnson, Phys. Rev. Lett., 51, 415-18 (1983).

20) H. Mori and H. Fujita, Proc. 5 th Japan Inst. Metals Int. Symp. on Non-Equilibrium Solid Phases of Metals and Alloys, Japan Inst. Metals, Sendai, 93-96 (1988).

21) H. Inui, H. Mori and H. Fujita, Acta Metall., 37, 1337-42 (1989) in press.

22) H. Fujita, Abst. of New Materials 88 Japan, Book of Abstracts, The 2 nd International New Materials Conference, Oct. , 11-14 (1988) pp. 274-83.

23) H. Fujita, J. Electron Microscopy Tech., 3, 45-56 (1986).

24）坂田孝夫, 森 博太郎, 藤田広志, セラミックス論文誌, 97, 295-301 (1989).

25) A. Inoue, A. Kitamura and T. Masumoto, Trans. JIM, 20, 404-06 (1979).

26) A. Audouard et al., Rad. Eff., 62, 161-65 (1982).

27) S. Banerjee and K. Urban, Phys. Stat. Sol. (a), 81, 145-62 (1984).

28) D. Turnbull, Scripta Met., 15, 1039-42 (1981).

29) N. Yoshida and M. Kiritani, J. Phys. Soc. Japan, 35, 1418-29 (1973). 